\title{
Isolation and Characterization of Fucoidan from Hizikia fusiformis (Hijiki)*
}

\author{
(Received October 17, 2002; Accepted February 10, 2003) \\ Riki Shiroma, ${ }^{1}$ Shuntoku Uechi, ${ }^{2}$ Tohki Taira, ${ }^{2}$ Masanobu Ishihara, ${ }^{2}$ \\ Shinkichi Tawata ${ }^{2}$ and Masakuni Tako ${ }^{2, * *}$ \\ 'The United Graduate School of Agricultural Sciences, Kagoshima University \\ (1-21-24, Korimoto, Kagoshima 890-0065, Japan) \\ ${ }^{2}$ Department of Bioscience and Biotechnology, Faculty of Agriculture, University of the Ryukyus \\ (1, Senbaru, Nishihara, Nakagami-gun, Okinawa 903-0213, Japan)
}

\begin{abstract}
The polysaccharide was isolated from Hizikia fusiformis (Hijiki), which was harvested in Okinawa Prefecture, Japan. The yield of the polysaccharide was $0.4 \%(\mathrm{w} / \mathrm{w})$ based on wet seaweed. The total carbohydrate, uronic acid, ash and sulfuric acid of the polysaccharide were $66.5,13.7,30.8$ and $26.3 \%$, respectively. After the acid hydrolysis of the polysaccharide, L-fucose, D-galactose, D-glucose, D-mannose, D-xylose and Dglucuronic acid were identified by liquid chromatography. The molar ratio of these sugar components and sulfuric acid was calculated to be L-Fuc : D-Gal : D-Glc : D-Man : D-Xyl : D-GlcA : $\mathrm{H}_{2} \mathrm{SO}_{4}=5: 1: 1: 0.5$ : $0.5: 2: 7$. The molecular mass of the polysaccharide was estimated by gel chromatography to be about $4.3 \times$ $10^{4}$. The IR spectrum of the polysaccharide was in agreement with that of standard fucoidan. The L-fucose, Dglucuronic acid and acetyl group were identified by ${ }^{1} \mathrm{H}$ - and ${ }^{13} \mathrm{C}$-NMR spectroscopy. The ${ }^{1} \mathrm{H}-\mathrm{NMR}$ spectraldata suggests that fucoidan is mainly composed of 3-linked unsulfated, 4-linked unsulfated, 3-linked 2-mono- $O$ sulfated, 4-linked 2-mono- $O$-sulfated and 3-linked 2,4-di- $O$-sulfated $L$-fucopyranose.

Key words: fucoidan, Hizikia fusiformis, NMR spectroscopy
\end{abstract}

Fucoidan is a complex sulfated polysaccharide found in the cell-wall matrix of brown algae and some echinoderms. Fucoidan has been extensively investigated because of its various biological activities as an anticoagulant, ${ }^{1-5)}$ antitumor ${ }^{6)}$ and antiviral ${ }^{7,8)}$ agents.

In previous paper, we isolated a fucoidan, which consisted of L-fucose, D-xylose, D-glucuronic acid, sulfuric acid and acetic acid in a molar ratio of $4.0: 0.03: 1.0$ : $2.0: 2.0$, from Cladosiphon okamuranus (Okinawamozuku $)^{9}$ which had been commercially cultured on artificially seeded nets $(1.5 \times 20 \mathrm{~m})$. The yield of the fucoidan was estimated to be $2.3 \%(\mathrm{w} / \mathrm{w})$ based on wet algae. This suggested that fucoidan could be commercially produced on a simple industrial scale from artificially cultured Okinawamozuku. ${ }^{10)}$ The annual production of the algae in Okinawa is reported to have been approximately $13,200 \mathrm{t}$ in 2002.

We also isolated a fucoidan, which consisted of Lfucose, D-galactose and sulfuric acid in a molar ratio of $1.0: 0.05: 1.0$, from Nemacystus decipiens (Itomozuku) which had also been commercially cultured on artificially seeded nets. ${ }^{11)}$ The yield of the fucoidan was estimated to be $0.5 \%(\mathrm{w} / \mathrm{w})$ based on wet algae. The annual production of the algae in Okinawa is reported to have been approximately 2,000 $\mathrm{t}$ in 2002. These seaweeds (Okinawamozuku and Itomozuku) are used in salad (Sunomono), so their utilization by the food industry has recently been increasing.

Hijiki (Hizikia fusiformis), one of the brown algae, is widespread in nature between Hokkaido and Okinawa

\footnotetext{
${ }^{*}$ Presented at the Annual Meeting of the Japanese Society of Carbohydrate Research, Yokohama, Japan, August 22-24, 2002.

${ }^{* *}$ Corresponding author (Tel. \& Fax. +81-98-895-8814, E-mail:tak @ agr.u-ryukyu.ac.jp).
}

Prefecture in Japan. The annual production of Hijiki, in Okinawa, is reported to have been approximately $120 \mathrm{t}$ in 2002. Fucoidan from Hijiki has been reported by Nishino et al.. ${ }^{12)}$ Nishide et al. ${ }^{13)}$ and Dobashi et al., ${ }^{(4)}$ but the polysaccharide from the algae harvested in Okinawa has not yet been studied. We report now the isolation and chemical characterization of fucoidan from the Hijiki.

\section{MATERIALS AND METHODS}

Materials. Hijiki (Hijikia fusiformis) used in this study was harvested in June 2001 from Yonabaru Town, Okinawa. The collected seaweed was washed with tap water and air-dried in oven an at $40^{\circ} \mathrm{C}$ for $24 \mathrm{~h}$. The dried seaweed was powdered in a blender.

Fucoidan used as the standard was extracted from $\mathrm{Fu}$ cus vesiculosus (Sigma Co., Ltd., USA).

Extraction and purification of the polysaccharide from Hijiki. The dried seaweed was suspended in $0.2 \mathrm{M}$ $\mathrm{HCl}$ and stirred at room temperature for $24 \mathrm{~h}$ for extraction of polysaccharide. The extract was then filtered through Celite 545 and neutralized with $0.5 \mathrm{M} \mathrm{NaOH}$. The neutralized solution was concentrated and precipitated by the addition of 2 volume of ethanol. The precipitate was dried in vacuo.

The crude polysaccharide was dissolved in $0.1 \mathrm{M} \mathrm{CaCl}_{2}$ solution and passed through Celite 545. The filtrate was dialyzed against distilled water overnight at room temperature and freeze-dried.

Purified polysaccharide was redissolved in distilled water and the solution deionized by passage through a column of Amberlite $120\left(\mathrm{H}^{+}\right)$, and then neutralized with $50 \mathrm{~mm} \mathrm{NaOH}$. The solution was filtered through Celite 545 again. The filtrate was dialyzed against distilled water 
over-night at room temperature and freeze-dried.

Deacetylation of polysaccharide. An aqueous $1.5 \%$ solution of the polysaccharide was treated under an atmosphere of nitrogen with $0.05 \mathrm{M} \mathrm{NaOH}$ at room temperature over-night to accomplish deacetylation. The solution was neutralized with $0.05 \mathrm{M} \mathrm{HCl}$, and then the product was dialyzed against distilled water and freeze-dried.

Chemical procedure. Total carbohydrate content was determined by the phenol-sulfuric acid method, ${ }^{15}$ ) using Lfucose as a standard. Uronic acid content was determined by the carbazole-sulfuric acid method, ${ }^{16)}$ using Dglucuronic acid as a standard.

Ester sulfate in the polysaccharide hydrolyzate, which had been treated by heating a $100^{\circ} \mathrm{C}$ for $3 \mathrm{~h}$ in a $2 \mathrm{M} \mathrm{HCl}$ solution, was determined by ion chromatograph DX500 (Dionex Co., Ltd., USA) on a column (AS4A $4 \times 250$ $\mathrm{mm}$ ) at a flow rate of $1 \mathrm{~mL} / \mathrm{min}$ at $35^{\circ} \mathrm{C}$. The column was developed with a $1.7 \mathrm{~mm} \mathrm{NaHCO}_{3}$ and $1.8 \mathrm{~mm}$ $\mathrm{Na}_{2} \mathrm{CO}_{3}$ solution.

Acid hydrolysis. Acid hydrolysis was carried out by dissolving the polysaccharide from Hijiki in distilled water and adding sulfuric acid to a final concentration 2.0 M. The mixture was heated at $100^{\circ} \mathrm{C}$ for $3 \mathrm{~h}$. The hydrolyzate was neutralized with $\mathrm{BaCO}_{3}$.

Liquid chromatography. The polysaccharide hydrolyzate was applied to a liquid chromatograph DX500 (Dionex Co., Ltd., USA) on a column (Carbopac PAL4 $\times 250$ $\mathrm{mm}$ ) equilibrated with $3 \mathrm{mM} \mathrm{NaOH}$ for neutral sugar and $100 \mathrm{mM} \mathrm{NaOH}+150 \mathrm{mM} \mathrm{CH}_{3} \mathrm{COONa}$ for D-glucuronic acid. The chromatography was carried out at a flow rate of $1 \mathrm{~mL} / \mathrm{min}$ at $35^{\circ} \mathrm{C}$.

Molecular mass. The molecular mass of the polysaccharide from Hijiki was determined by high-performance liquid chromatography (HPLC) (LC-6A; Shimadzu Co., Japan) with a column of TSKgel PWXL $(7.8 \times 300 \mathrm{~mm}$, Tosoh Co., Japan) and detected with a refractive index detector RID-6A (Shimadzu Co., Japan) at room temperature. The column was eluted by $150 \mathrm{mM} \mathrm{NaCl}$ in a 50 $\mathrm{mM}$ phosphate buffer $(\mathrm{pH} 7.2)$ at a flow rate of $0.3 \mathrm{~mL} /$ min. Pullulan P-5 $\left(\mathrm{M}_{\mathrm{w}}=0.59 \times 10^{4}\right), \mathrm{P}-20\left(2.28 \times 10^{4}\right), \mathrm{P}-$ $100\left(11.2 \times 10^{4}\right)$ and P-400 $\left(40.4 \times 10^{4}\right)$ (Showa Denko Co., Japan) were used as the molecular weight standards.

Optical rotation. Optical rotation of the polysaccharide from Hijiki was measured at $589 \mathrm{~nm}$ on a polarimeter DIP-180 (Japan Spectroscopic Co., Ltd., Japan) for a $0.2 \%(\mathrm{w} / \mathrm{v})$ solution in distilled water.

Infrared spectra. Infrared spectra were recorded with an Infrared spectrometer FTS-3000 (Bio-Rad Lab., Inc., USA) for a sample dispersed in $\mathrm{KBr}$ discs.

${ }^{1} \mathrm{H}$ - and ${ }^{13} \mathrm{C}$-Nuclear magnetic resonance (NMR) spectroscopy. The ${ }^{1} \mathrm{H}$ - and ${ }^{13} \mathrm{C}-\mathrm{NMR}$ spectra were recorded on a FT-NMR spectrometer JNM-A500 (Nihondenshi Co., Ltd., Japan) at 500.00 and $125.65 \mathrm{MHz}$, respectively. The polysaccharide $(5 \%)$ was dissolved in $\mathrm{D}_{2} \mathrm{O}$, and the data recorded at $60^{\circ} \mathrm{C}$. The ${ }^{1} \mathrm{H}$ - and ${ }^{13} \mathrm{C}-\mathrm{NMR}$ chemical shifts are expressed in parts per million (ppm) relative internal sodium 3-(trimethylsilyl)propionic-2,2,3,3-d4 (TSP, 0.00 ppm).

\section{RESULTS AND DISCUSSION}

The harvested seaweed (2000 g) was washed with tap water and then air-dried in an oven at $40^{\circ} \mathrm{C}$ for $24 \mathrm{~h}$. The weight of the air-dried seaweed decreased to $280 \mathrm{~g}$. The polysaccharide from Hizikia fusiformis (Hijiki) was extracted in $0.2 \mathrm{M} \mathrm{HCl}$ and purified as described in MATERIALS AND METHODS. The yield of the purified polysaccharide was $0.4 \%$ based on wet seaweed.

The total carbohydrate, uronic acid and ash of the polysaccharide were $66.5,13.7$ and $30.8 \%$, respectively. The sulfuric acid content of the polysaccharide was estimated to be $26.3 \%$ (Table 1 ).

The polysaccharide hydrolyzate was applied to a liquid chromatograph and L-fucose, D-galactose, D-glucose, Dmannose and D-xylose were detected (Fig. 1(A)). The uronic acid of polysaccharide component was confirmed to D-glucuronic acid by a liquid chromatograph (Fig. 1(B)). According to each percentage of total carbohydrate, uronic acid and sulfuric acid content, the molar ratio of these sugar components and sulfuric acid was calculated to be L-Fuc : D-Gal : D-Glc : D-Man : D-Xyl : DGlcA : $\mathrm{H}_{2} \mathrm{SO}_{4}=5: 1: 1: 0.5: 0.5: 2: 7$ (Table 2). The results differed from fucoidans isolated from Hijiki which were harvested on the main is lands of Japan (Fuc : Xyl : Man : Gal : GlcA : $\mathrm{H}_{2} \mathrm{SO}_{4}=6: 1: 1: 3: 4.5: 9$ by Nishino et al. ${ }^{12)}$; Fuc : Uronic acid : $\mathrm{H}_{2} \mathrm{SO}_{4}=1: 0.56$ : 3.03 by Nishide et al.$^{13)}$; Fuc : Xyl : Man : Gal : GlcA : $\mathrm{H}_{2} \mathrm{SO}_{4}=100: 1: 6: 6: 3: 186$ by Dobashi et al ${ }^{14)}$.

The molecular mass of purified polysaccharide was es-

Table 1. Chemical components of polysaccharide from Hijiki (\%, $\mathrm{w} / \mathrm{w})$

\begin{tabular}{ccccc}
\hline & Carbohydrate & Uronic acid & Ash & $\mathrm{H}_{2} \mathrm{SO}_{4}$ \\
\hline Polysaccharide & 66.5 & 13.7 & 30.8 & 26.3 \\
\hline
\end{tabular}

Table 2. Molar ratio of the sugar components and sulfuric acid of polysaccharide from Hijiki.

\begin{tabular}{ccccccc}
\hline L-Fuc & D-Gal & D-Glc & D-Man & D-Xyl & D-GlcA & $\mathrm{H}_{2} \mathrm{SO}_{4}$ \\
\hline 5 & 1 & 1 & 0.5 & 0.5 & 2 & 7 \\
\hline
\end{tabular}

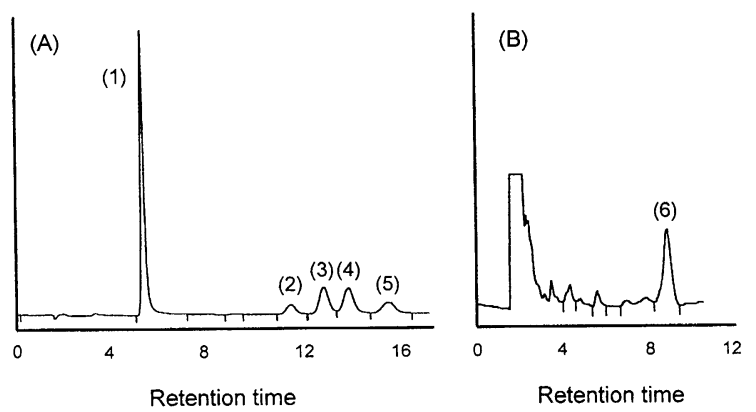

Fig. 1. Liquid chromatogram of the polysaccharide from Hijiki.

(A): (1) L-fucose, (2) D-xylose, (3) D-galactose, (4) D-glucose, (5) D-mannose. Column, Carbopac PAL $(4 \times 250 \mathrm{~mm})$; eluent, 3 $\mathrm{mM}$ sodium hydroxide; eluent flow, $1 \mathrm{~mL} / \mathrm{min}$. (B): (6) Dglucuronic acid. Column, Carbopac PAL $(4 \times 250 \mathrm{~mm})$; eluent, $100 \mathrm{mM}$ sodium hydroxide $+150 \mathrm{~mm}$ sodium acetate; eluent flow, $1 \mathrm{~mL} / \mathrm{min}$. 
timated with pullulan as standards to be about $4.3 \times 10^{4}$ by gel permeation chromatography with a column of TSKgel PWXL (Fig. 2).

The optical rotation of the polysaccharide $(0.2 \%, \mathrm{w} / \mathrm{v})$ showed a value of $-0.032^{\circ}$ at $60^{\circ} \mathrm{C}$ and decreased a little with decreasing temperature to a value of $-0.035^{\circ}$ at $10^{\circ} \mathrm{C}$ (Table 3 ).

The infrared spectrum of the polysaccharide is shown in Fig. 3(A). The spectrum indicated a hydroxyl group at $3400 \mathrm{~cm}^{-1}$ and a sulfate group at $1255 \mathrm{~cm}^{-1}$. ${ }^{17)}$ Besides chemical analysis, it also became clear that a sulfate group is included in the polysaccharide from Hijiki with IR spectrum. A small shoulder of absorption at $1720 \mathrm{~cm}^{-1}$

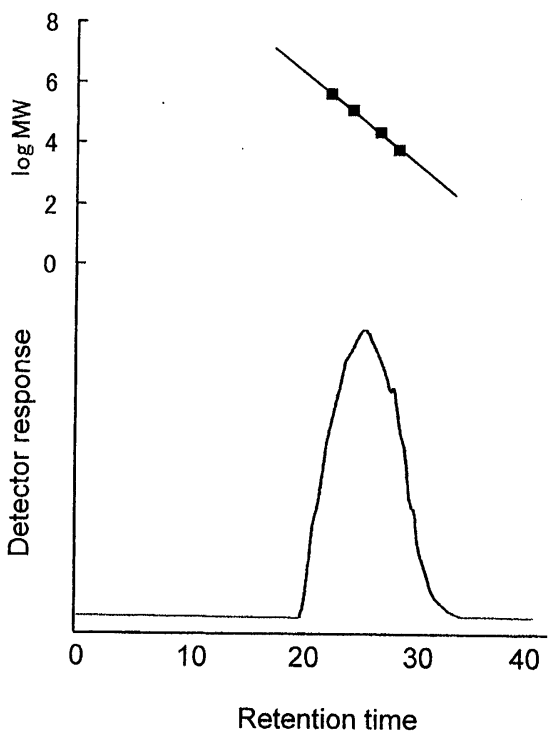

Fig. 2. Gel permeation chromatogram of polysaccharide from Hijiki.

Column, TSKgel PWxL $(7.8 \times 300 \mathrm{~mm})$; eluent, $150 \mathrm{mM}$ sodium chloride in a phosphate buffer $(\mathrm{pH} 7.2)$; eluent flow, $0.3 \mathrm{~mL} / \mathrm{min}$. The calibration curve was made with pullulan with molecular masses of $40.4,11.2,2.28$ and $0.59 \times 10^{4}$ as a standard.

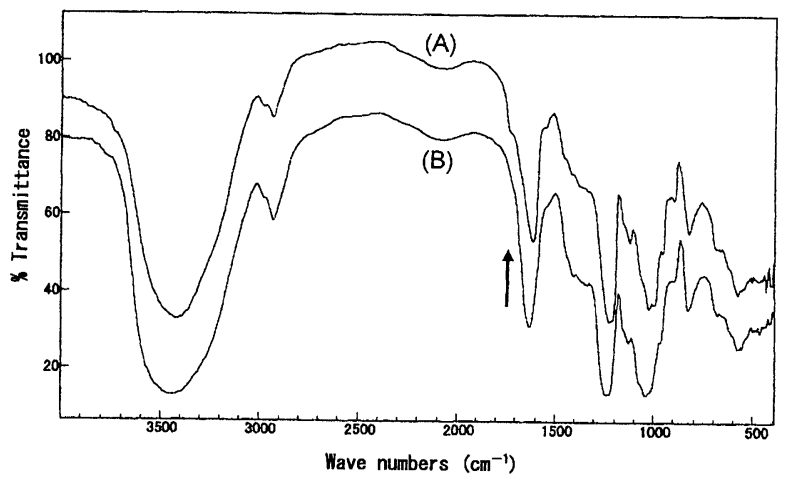

Fig. 3. Infrared spectra of the purified polysaccharide from Hijiki at $4000-400 \mathrm{~cm}^{-1}$.

(A), native polysaccharide; (B), alkaline-treated polysaccharide. Arrow shows disappearance of absorption at $1720 \mathrm{~cm}^{-1}$.

Table 3. Optical rotation of the polysaccharide from Hijiki at $589 \mathrm{~nm}$.

\begin{tabular}{|c|c|c|c|c|c|c|c|}
\hline & \multicolumn{7}{|c|}{ Temperature $\left({ }^{\circ} \mathrm{C}\right)$} \\
\hline & 10 & 20 & 25 & 30 & 40 & 50 & 60 \\
\hline $\begin{array}{l}\alpha \\
\text { degree }\end{array}$ & -0.035 & -0.034 & -0.033 & -0.033 & -0.033 & -0.032 & -0.032 \\
\hline
\end{tabular}

was observed in the polysaccharide. The spectrum was in agreement with that of standard fucoidan (Figure not shown). The spectrum of alkaline treated polysaccharide is shown in Fig. 3(B). After the alkaline treatment of native polysaccharide, a small shoulder of absorption at $1720 \mathrm{~cm}^{-1}$ disappeared. This may be due to deesterification of the polysaccharide. ${ }^{18)}$

The ${ }^{1} \mathrm{H}-\mathrm{NMR}$ spectra of native (A) and alkaline treated (B) polysaccharide are shown in Fig 4. The chemical shift of the envelope of anomeric signals of the native polysaccharide (A) at 5.0-5.5 ppm is consistent with the presence of $\alpha$-L-fucopyranosyl units. ${ }^{19)}$ The signals at 5.41, 5.33, $5.22,5.11$ and $5.04 \mathrm{ppm}$ can be assigned to 4-linked 2mono- $O$-sulfated, 3-linked 2,4-di- $O$-sulfated, 3-linked 2mono- $O$-sulfated, 4-linked unsulfated and 3-linked unsulfated L-fucopyranose. ${ }^{11,18-20)}$ The signals at $2.2-2.0 \mathrm{ppm}$ were assigned to the methyl protons of the acetyl group. ${ }^{10)}$ The signals at $1.5-1.1 \mathrm{ppm}$ were assigned to the methyl proton group of the L-fucopyranose ${ }^{10)}$ where $1.41,1.24$ and $1.18 \mathrm{ppm}$ can be assigned to 4-linked 2-mono- $O$ sulfated, 3-linked 2-mono- $O$-sulfated and 3-linked unsulfated L-fucopyranose, ${ }^{18)}$ respectively. The signals at $2.2-$ $2.0 \mathrm{ppm}$ of the alkaline treated polysaccharide (B) disappeared. The result indicates that the acetyl groups were removed by alkaline treatment. ${ }^{10)}$

The ${ }^{13} \mathrm{C}$-NMR spectra of native (A) and alkaline treated (B) polysaccharide from Hijiki are shown in Fig. 5. The signals of the spectrum of native polysaccharide (A) in the range of $20.0^{-18.5} \mathrm{ppm}$ assigned to the methyl carbon group of the L-fucopyranose, ${ }^{17)}$ in the range of 87.4-63.6 ppm assigned to the ring carbons and in the range of
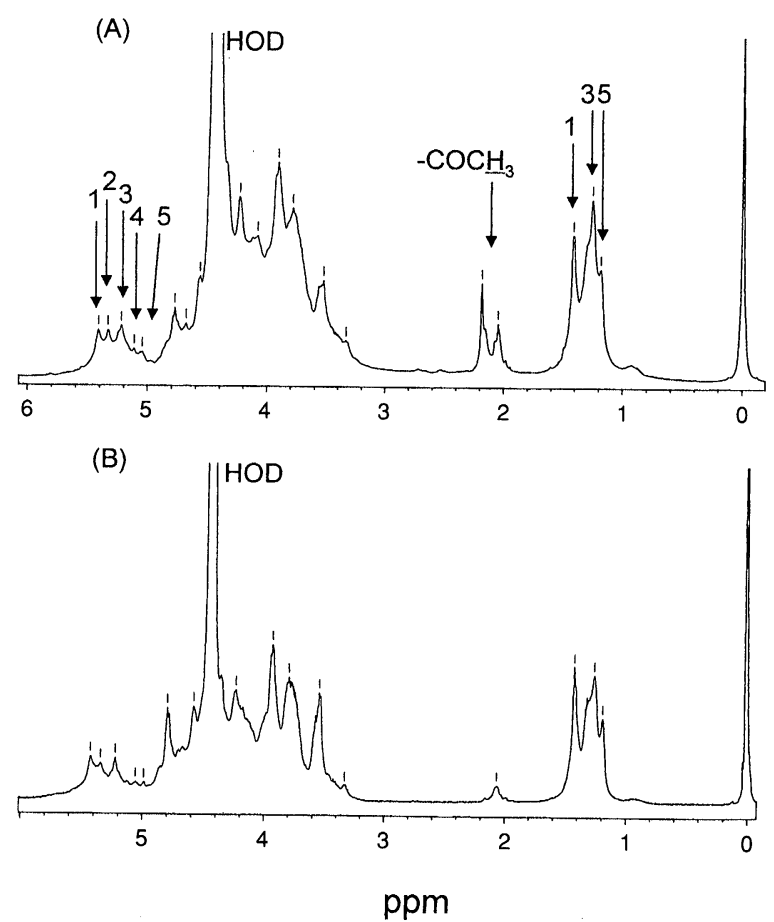

Fig. 4. ${ }^{1} \mathrm{H}-\mathrm{NMR}$ spectra of the polysaccharide from Hijiki in $\mathrm{D}_{2} \mathrm{O}$, at $60^{\circ} \mathrm{C}$.

(A), native polysaccharide; (B), alkaline-treated polysaccharide. 1,4-linked 2-mono- $O$-sulfated L-fucopyranose; 2,3-linked 2,4-di- $O$ sulfated L-fucopyranose; 3,3-linked 2-mono- $O$-sulfated Lfucopyranose; 4,4-linked unsulfated L-fucopyranose; 5,3-linked unsulfated L-fucopyranose. 
(A)

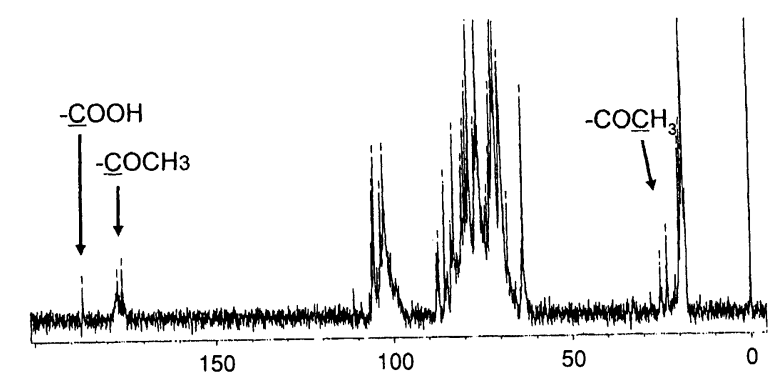

(B)

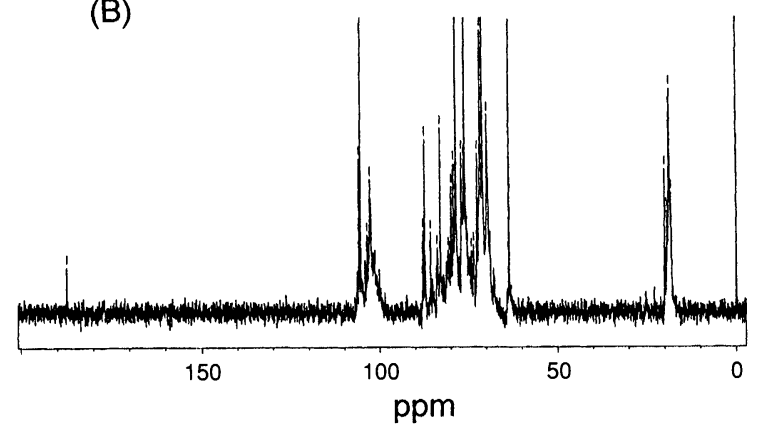

Fig. 5. ${ }^{13} \mathrm{C}-\mathrm{NMR}$ spectra of the polysaccharide from Hijiki in $\mathrm{D}_{2} \mathrm{O}$, at $60^{\circ} \mathrm{C}$.

(A), native polysaccharide; (B), alkaline-treated polysaccharide.

105.8-102.6 ppm assigned to the anomeric carbons. The signals were complicated and these analysis are difficult. However, the disappearance of four signals were observed in the spectrum of alkaline treated polysaccharide (B). The disappearing signals of 25.3 and $23.4 \mathrm{ppm}$ were methyl carbons of acetyl group ${ }^{10,20)}$ and that of 177.2 and $175.9 \mathrm{ppm}$ were considered to be carbonyl carbons of acetyl group. ${ }^{10)}$ Therefore, the remaining signal of 187.4 ppm in low-field was assigned to the carbonyl carbon of D-glucuronic acid.

These results indicated that the polysaccharide from Hijiki is a fucoidan. Sulfate and acetyl groups were included in Hijiki fucoidan which were confirmed by IR and NMR spectroscopy, particularly, the sulfate groups attached to the $\mathrm{C}-2$ or $\mathrm{C}-2$ and $\mathrm{C}-4$ of $\alpha$-L-fucopyranosyl residues which was confirmed by 'H-NMR spectroscopy. It is reported that fucoidan's molar ratio of neutral sugars and ester sulfate affect its biological activities. ${ }^{21,22)}$ In particular, fucoidan from Hijiki collected in the main islands had anticoagulant activity, ${ }^{14)}$ so fucoidan from Hijiki collected in Okinawa also has to have this activity. Other biological activities of fucoidan from Hijiki collected in Okinawa, including more detailed structural analysis, are now under investigation.

In conclusion, it was elucidated here that Hijiki (Hizikia fusiformis) from Okinawa can be used as a source of fucoidan, the same as Okinawamozuku (Cladosiphon okamuranus) ${ }^{10)}$ and Itomozuku (Nemacystus decipiens). ${ }^{11}$

We thank Yonabaru Nishihara Town Fisherman's Union for the gift of a sample of Hijiki (Hizikia fusiformis).

\section{REFERENCES}

1) T. Nagumo and T. Nishino: Fucan sulfates and their anticoagulant activities. in Polysaccharide in Medical Applications, S. Dumitrius, ed., Marcel Dekker, New York, pp. 545-574 (1996).

2 ) W.M. Doane and R.L. Whistler: Comparison of the anticoagulant activity of three polysaccharide sulfates. Arch. Biochem. Biophys., 101, 436-438 (1963).

3 ) T. Nishino, H. Ura and T. Nagumo: The relationship between the sulfate content and antithrombin activity of an $\alpha-(1 \rightarrow 2)$ fucoidan purified from a commercial fucoidan fraction. Bot. Mar., 38, 187-193 (1995).

4 ) T. Nishino, A. Fukuda, T. Nagumo, M. Fujihara and E. Kaji: Inhibition of the generation of thrombin and factor $\mathrm{Xa}$ by a fucoidan from the brown seaweed Ecklonia kurome. Thromb. Res., 96, 37-49 (1999).

$5)$ L. Chevolot, A. Faucault, N. Kervarec, C. Sinquin, A.M. Fischer and C. Boisson-vidal: Further data on the structure of brown seaweed fucans: Relationships with anticoagulant activity. Carbohydr. Res., 319, 154-165 (1999).

$6)$ H. Itoh, H. Noda, H. Amano, C. Zhuang, T. Mizuno and H. Itoh: Antitumor activity and immunological properties of marine algal polysaccharide, especially fucoidan, prepared from Sargassum thunbergii of Phaeophyceae. Anticancer Res., 13, 2045-2052 (1994).

7 ) M. Baba, R. Snock, R. Pauwels and E. DeClercq: Sulfated polysaccharide are potent and selective inhibitors of various enveloped viruses, including herpes simplex virus, cytomegalovirus, vesicular stomatitis virus and human immunodeficiency virus. Antimicrob. Agents Chemother., 32, 1742-1745 (1988).

8 ) M.O. McClure, J.P. Moore, D.F. Blanc, P. Scotting, G.M.W. Cook, R.J. Keynes, J.N. Weber, D. Davies and R.A. Weiss: Investigation into the mechanism by which sulfated polysaccharides inhibit HIV infection in vitro. AIDS Res. Hum. Retrovir., 8, 19-26 (1992).

9 ) M. Tako, M. Uehara, Y. Kawashima, H. Shyo, I. Chinen and F. Hongo: Isolation and characterization of fucoidan from Okinawamozuku (Cladosiphon okamuranus Tokida). J. Appl. Glycosci., 43, 143-148 (1996).

10) M. Tako, E. Yoza and S. Tohma: Chemical characterization of acetyl fucoidan and alginate from commercially cultured Cladosiphon okamuranus. Bot. Mar., 43, 393-398 (2000).

11) M. Tako, T. Nakada and F. Hongo: Chemical characterization of fucoidan from commercially cultured Nemacystus decipines (Itomozuku). Biosci. Biotechnol. Biochem., 63, 1813-1815 (1999).

12) T. Nishino and T. Nagumo: Sugar constituents and bloodanticoagulant activities of fucose-containing sulfated polysaccharides in nine brown seaweed species. Nippon Nogeikagaku Kaishi, 61 361-363 (1987).

13) E. Nishide, H. Anzai and N. Uchida: A comparative investigation on the contents of fucose-containing polysaccharides from various Japanese brown algae. Nippon Suisan Gakkaishi, 53, 1083-1088 (1987).

14) K. Dobashi, T. Nishino, M. Fujihara and T. Nagumo: Isolation and preliminary characterization of fucose-containing sulfated polysaccharides with blood-anticoagulant activity from the brown seaweed Hizikia fusiforme. Carbohydr. Res., 194, 315320 (1989).

15) M. Dubois, K.A. Gills, J.K. Hamilton, P.A. Rebers and F. Smith: Colorimetric method for determination of sugars and related substances. Anal. Chem., 28, 350-356 (1956).

16) J.T. Galambos: The reaction of carbozole with carbohydrate. Anal. Biochem., 19, 119-132 (1967).

17) M.S. Patanker, S. Oehninger, T. Barnett, R.L. Williams and G. F. Clark: A revised structure for fucoidan may explain some of its biological activities. J. Biol. Chem., 268, 21770-21776 (1993).

18) M.I. Bilan, A.A. Grachev, N.E. Ustuzhanina, A.S. Shashkov, N.E. Nifantiev and A.I. Usov: Structure of fucoidan from the 
brown seaweed Fucus evanescens C. Ag. Carbohydr. Res., 337, 719-730 (2002)

19) B. Mulloy, A.-C. Ribeiro, A.-P. Alves, R.P. Vieira and P.A.S. Mourão: Sulfated fucans from Echinoderms have a regular tetrasaccharide repeating unit defined by specific patterns of sulfation at the $O-2$ and $O-4$ positions. J. Biol. Chem., 269, 22113-22123 (1994).

20) A.-C. Ribeiro, R.P. Vieira, P.A.S. Mourão and B. Mulloy: A sulfated $\alpha$-L-fucan from sea cucumber. Carbohydr. Res., 255, 225-240 (1994).

21) M.E.R. Duarte, M.A. Cardoso, M.D. Noseda and A.S. Cerezo: Structural studies on fucoidans from the brown seaweed Sargassum stenophyllum. Carbohydr. Res., 333, 291-293 (2001).

22) B. Mulloy, P.A.S. Maurão and E. Gray: Structure/function studies of anticoagulant sulphated polysaccharide using NMR. J. Biotechnol., 77, 123-135 (2000).
沖縄産ヒジキからのフコイダンの分離・同定

城間 力', 上地俊徳 ${ }^{2}$, 平良東紀 ${ }^{2}$,

石原昌信 ${ }^{2}$, 多和田真吉 ${ }^{2}$, 田幸正邦 ${ }^{2}$

' 鹿児島大学大学院連合農学研究科

（890-0065 鹿児島市郡元 1-21-24）

${ }^{2}$ 琉球大学農学部生物資源科学科

（903-0213 沖縄県中頭郡西原町字千原 1)

沖縄産ヒジキから塩酸溶液により多糖を抽出した。常 法により精製した多糖の全糖，ウロン酸，灰分および硫 酸含量はそれぞれ66.5，13.7，30.8および $26.3 \%$ おっ た。構成糖は L-Fuc, D-Gal, D-Glc, D-Man, D-Xyl および D-GlcA で, その比率は L-Fuc：D-Gal：D-Glc：D-Man：DXyl : D-GlcA $: \mathrm{H}_{2} \mathrm{SO}_{4}=5: 1: 1: 0.5: 0.5: 2: 7$ と算出さ れた.プルランを標準物質としたゲル濾過法により, ヒ ジキ精製多糖の分子量は約 43,000 と見積もられた。精製 多糖の IR スペクトルは標本フコイダンと広い波数領域で のよい一致を示し, ${ }^{1} \mathrm{H}-お よ ひ ゙{ }^{13} \mathrm{C}-\mathrm{NMR}$ スペクトルから Lフコース残基，D-グルクロン酸残基およびアセチル基の 存在が確認された。 ${ }^{1}$ H-NMR スペクトルより 3-linked unsulfated, 4-linked unsulfated, 3-linked 2-mono- $O$-sulfated, 4linked 2-mono-O-sulfated および 3-linked 2,4-di- $O$-sulfated Lfucopyranose が存在することが示唆された。 